\title{
VARIABILITY IN ETHIOPIAN CORIANDER ACCESSIONS FOR AGRONOMIC AND QUALITY TRAITS
}

\author{
BEEMNETMENGESHA and GETINET ALEMAW ${ }^{1}$ \\ Wondo Genet Agricultural Research Center, P. O. Box 198, Shashemene, Ethiopia \\ ${ }^{1}$ Melkasa Agricultural Research Center, P. O. Box 436 Nazareth, Ethiopia \\ Corresponding author: mengeshabeemnet@yahoo.com
}

(Received 4 June, 2009; accepted 25 May, 2010)

\begin{abstract}
Coriander (Coriandrum sativum L.) is an annual spice herb that belongs to the family of Umbelliferae/Apiaceae. Although Ethiopia is known as a primary diversity for coriander, the knowledge on nature and extent of variation of the indigenous germplasm is limited. Hence, to address the nature and extent of variability on agronomic and chemical traits, test trial was conducted at Kokate and Wondo Genet, Southern Ethiopia, using 49 accessions arranged in randomised complete block design in two replications during the main season of 2007/08. Data for 15 agronomic and quality traits were measured and statistically tested. In the combined analysis of variance over locations, accessions varied significantly in all the traits except for basal leaf number, plant height and fatty oil contents. The interaction between accessions and environment was significant for nine of the 15 traits. A range of seed yield (910-3099 kg ha-1), essential oil (0.25-0.85\%) and fatty oil (11.11-16.53\%) content was obtained. Overall, highest value of genetic coefficient of variation, broad sense heritability and genetic advance as percent of mean was obtained for longest basal leaf length, days to start $50 \%$ flowering, umbels number/plant, umbellets number/umbel, seed number/umbellets, seed number/plant, seed yield/ha and essential oil content.
\end{abstract}

Key Words: Coriandrum sativum, essential oil, Ethiopia, fatty oil

\section{RÉSUMÉ}

Bien que l’Éthiopie est connue comme étant une diversité primaire de coriandre (Coriandrum sativum L.), la connaissance de la nature et du niveau de variation de son germoplasm indigène est limitée. Ainsi, pour étudier sa nature et son niveau de variabilité sur les paramètres agronomiques et chimiques, un essai était effectué durant la saison 2007-2008 à Kokate et Wondo Genet au sud de l' Ethiopie, utilisant 49 accessions disposées en blocs complètement randomisés avec deux répétitions. Les données de 15 paramètres agronomiques et de qualité ont été mesurées et statistiquement testées. En faisant l'analyse combinée de la variance sur les sites, les accessions ont significativement varié dans tous les paramètres à l'exception du nombre de feuilles basales, de la hauteur de plants et de la teneur en huile grasse. L'interaction entre les accessions et l'environnement a été significative pour neuf des 15 paramètres. Une gamme de rendement en grains ( $\left.910-3099 \mathrm{~kg} \mathrm{ha}^{-1}\right)$, en huile essentielle $(0.25$ à $0.85 \%)$ et de la teneur en huile grasse (11.11 à 16.53\%) était obtenue. Dans l'ensemble, la valeur la plus élevée du coefficient de variation génétique, l’héritabilité au sens large et un développement génétique avancé comme poucentage de la moyenne était obtenue pour la longueur de la feuille basale la plus longue, les jours précédant $50 \%$ de la floraison, le nombre d'ombelles par plant, le nombre d'ombellets par ombelle, le nombre de grains par ombellets, le nombre de grains par plant, le rendement en grains par hectare et la teneur en huile esentielle.

Mots Clés: Coriandrum sativum, huile essentielle, Ethiopie, huile grasse 


\section{INTRODUCTION}

Coriander (Coriandrum sativum L.) is an annual spice herb that belongs to the family of Umbelliferae/Apiaceae (Hedburg and Hedburg, 2003). It is used as a spice in culinary (Diederichsen, 1996), medicine (Kubo et al., 2004; Delaquis et al., 2002) and; in perfumery, food, beverage, and pharmaceuticals industries (Jansen, 1981). Coriander is also a good melliferous plant and studies indicated that one hectare of coriander allows honey bees to collect about $500 \mathrm{~kg}$ of honey (Romanenko et al., 1991). The seed contains significant quantities of carotene, thiamine, riboflavin, niacin, tryptophase, vitamin B6, folate, vitamin C and $\mathrm{E}$ (Holland et al., 1991); iron, manganese, magnesium and dietary fiber to the diet (Ensminger and Esminger, 1986).

Although coriander has got diverse uses and Ethiopia is a center of primary diversity for the crop (Jansen, 1981), the knowledge on the extent and magnitude of genetic variability of agronomic and quality traits is limited. The existence of sufficient level of genetic variability is a prerequisite for variety development, hence, detailed appraisal of the accessions for different morphological, agronomic and quality traits is necessary in order to identify useful traits either for direct use or pave a way for other improvement programs. This study was designed to assess the nature and extent of variation that exists in Ethiopian coriander accessions for different agronomical and selected chemical traits.

\section{MATERIALS AND METHODS}

The experiment was conducted in two locations of Southern Ethiopia at Kokate and Wondo Genet Agricultural Research Center during the main cropping season of 2007/2008. Kokate is located at $6^{\circ} 532 \mathrm{~N}$ latitude and $37^{\circ} 522 \mathrm{E}$ longitude with an altitude of 2100 m.a.s.l. It has a humid climate with an average annual temperature of $18^{\circ} \mathrm{C}$, and average annual precipitation of about $1300 \mathrm{~mm}$. The soil is sandy loam with a $\mathrm{pH}$ of 4.81 .

Wondo Genet is located at $7^{\circ} 192 \mathrm{~N}$ latitude and $38^{\circ} 382 \mathrm{E}$ longitude with an altitude of 1780 m.a.s.l. The site receives mean annual rainfall of $1000 \mathrm{~mm}$ with maximum and minimum temperature of 10 and $30^{\circ} \mathrm{C}$, respectively. The soil is sandy clay loam with an average $\mathrm{pH}$ of 7.2.

The experiment consisted of 49 accessions arranged in randomised complete block design with two replications. The plot size was $3.6 \mathrm{~m}^{2}$ with six rows having $6 \mathrm{~m}$ length and $0.4 \mathrm{~m}$ interrow spacing. Seeds were drilled in rows on 15 July 2007 at Kokate, and 18 July 2007 at Wondo Genet. Two hoeing and three weddings were carried out and no fertiliser or other chemicals were applied.

Data on basal leaf number, longest basal leaf length, plant height, days to start 50\% flowering, days to end $50 \%$ flowering, days to reach $50 \%$ maturity, umbels number/plant, umbellets number/umbel, seed number/umbellets, 1000 seed weight, seed yield/plant, seed yield/ha, essential and fatty oil contents were collected from plants in a middle rows of a plot. Description and measurements of traits were taken according the methods of International Plant Genetic Resource Institute (Diederichsen, 1996).

Essential oil content was determined on volume by dry weight (v/w) basis from 50-100 g sun-dried composite seeds from three middle row plants of a plot. The laboratory analysis was done at Wondo Genet Agricultural Research Center. Essential oil was determined by hydro-distillation as illustrated by Guenther (1972). Hydrodistillation is a distillation method in which the plant material to be distilled (in this case the coriander seeds) comes in direct contact with the boiling water. Heat was provided by electromantle. The emerging vapour from the flask containing the volatile essential oil was led to a condenser for condensation and collected in the oil separate unit.

Fatty oil content was determined from an oven dried 22 g composite seed samples taken from the three middle rows of each plot by subjecting in to the Nuclear Magnetic Resonance Spectrometer reader (NMRS). The laboratory analysis was done at Holetta Agricultural Research Center.

Variability among accessions was estimated using range, mean, least significant difference, phenotypic and genotypic variance and coefficient of variability according to Burton and Devane (1953). Analysis of variance of the traits was computed using SAS computer program 
(SAS 2001). Broad sense heritability, genetic advance and genetic advance as percent of the mean were analyzed according to Johnson et al. (1955).

\section{RESULT AND DISCUSSION}

Estimates of mean squares, range, mean and standard errors from combined analysis of variance for 15 traits of 49 Ethiopian coriander accessions over two locations is shown on Table 1. The result shows highly significant variation $(\mathrm{P}<0.01)$ among the accessions for 11 of the 15 traits, significant variation $(\mathrm{P}<0.05)$ for number of days to end of $50 \%$ flowering and insignificant ( $P>0.05$ ) for basal leaf number, plant height and fatty oil content. Location had a significant $(\mathrm{P} \leq 0.05)$ effect on basal leaf number, days to harvest, umbels number/plant, seed yield/plant and fatty oil content. The significance of location effect was expected at both Kokate and Wondo Genet because they vary in soil type, annual rainfall and temperature. The interaction effects of environment and accessions were highly significant $(\mathrm{P}<0.01)$ for the longest basal leaf length, basal leaf number, plant height, umbels number/plant, seed yield/plant, essential oil and fatty oil contents, thus, indicating performance inconsistency of accessions to varied environments; hence, wider agro-ecological test trial is inquired to evaluate these traits.

Seed yield ranged from 910.6 (accession 207516) to 3099.9 (accession 240803), essential oil content from $0.25 \%$ (accession 203068) to $0.85 \%$ (accession 240573) and fatty oil content from $11.11 \%$ (accession 240570) to $16.53 \%$ (accession 208026). The ranges, means and standard deviations observed in this study were comparable to the reports of Diederichsen (1996). The basal leaf number among the 49 accessions ranged from $7-23$ with a mean of 16 . This value is higher than what was reported by Diederichsen (1996). The leaves of coriander are consumed as herb and some of these accessions with higher and larger leaves can be cultivated as herbs. The weight of thousand seeds of the tested accessions ranged from 9.8 to $12.8 \mathrm{~g}$, which is in agreement with the previous studies of Arganosa et al. (1998). Furthermore, Diederichsen (1996) reported that larger seed size is correlated with higher essential oil contents and, thus, selection for larger seed size may be necessary to maximise essential oil contents in Ethiopian germplasm. The range from $11.1-16.3 \%$ for fatty oil and 0.25 $0.85 \%$ for essential oils content among the 49 accessions in this study were inclusive within the ranges reported by of Diederichsen (1996) which was $9.9-27.7 \%$ for fatty oil and $0.03-2.60$ for essential oil contents. The wider ranges of traits reported by of Diederichsen (1996) could be due to the larger sample size of 237 world coriander collections.

Estimates of genetic variance ranged from 0.01 for essential oil content to 300628.8 for seed number/plant. The range of phenotypic variance was 0.02 for essential oil content and 361657.6 for seed number/plant (Table 2). Genetic variance was larger for the longest basal leaf length, days to reach $50 \%$ maturity, umbels number/plant, umbellets number/umbel, seed number/plant, seed yield/plant and seed yield. Therefore, the higher proportion of phenotypic variance observed on these traits was due to the larger proportion of genotypic variance. According to Miller et al. (1957), these traits can be utilised in breeding programme to evaluate coriander accessions for seed yield by using few replicates, location and years.

The higher value of genotypic coefficient of variability ( $>10 \%$ ) was obtained for most of the traits considered except for basal leaf number, plant height, 1000 seed weight, days to start 50\% flowering and days to reach $50 \%$ maturity (Table 2 ) indicating that these traits were least affected by the environment. Genetic coefficient of variation indicates the genetic variability present in various quantitative characters without the level of heritability. Genetic coefficient of variation together with heritability estimates would give the best indication of the amount of gain due to selection (Johnson et al., 1955).

Broad sense heritability of more than $50 \%$ was obtained for 11 of the 15 characters (Table 2). The highest heritability estimates were obtained for seed number/plant (83\%) and seed yield/plant (83\%); and lower for fatty oil content (14.75\%), basal leaf number (14\%) and plant height (39\%). The value of heritability for seed yield, fatty and essential oils were lower than $40 \%$. Similar lower values of heritability for seed yield, essential and 


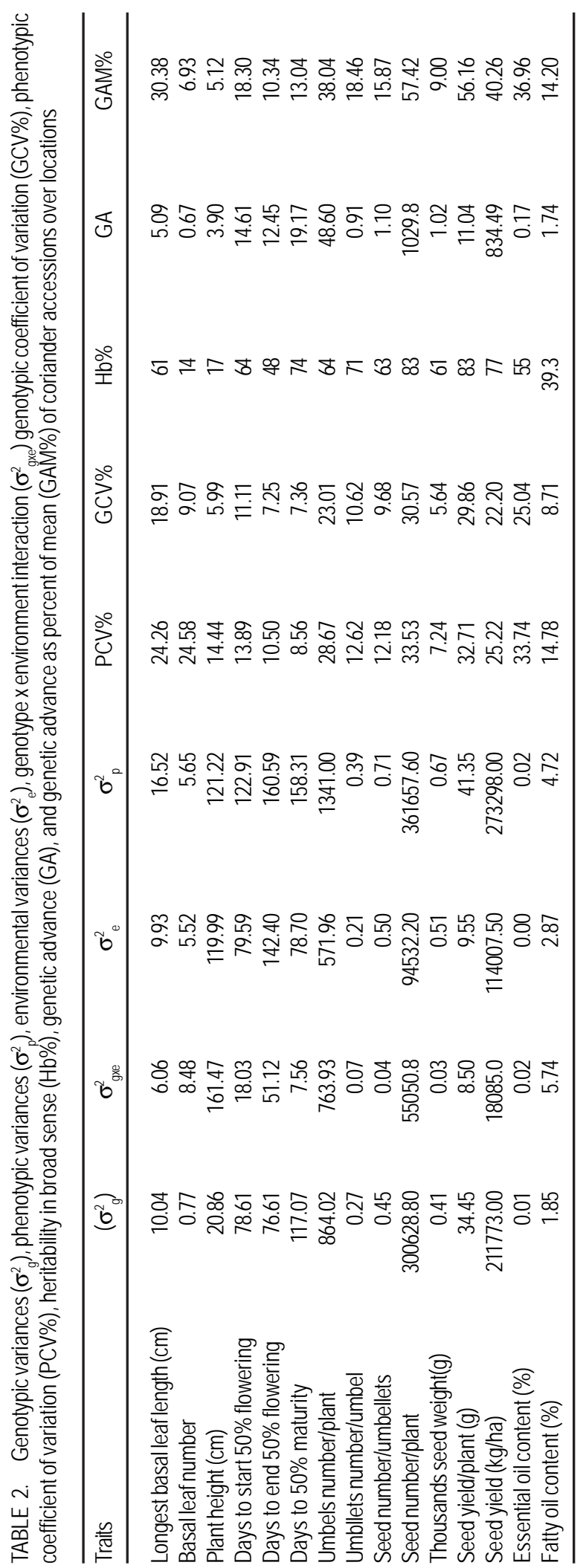


fatty oils were also reported by Adam et al. (2007) for black cumin. When heritability of a character is very high (>80\%), selection for such character may be fairly easy owing to close correspondence between the genotypes and the phenotypes arising from a relatively smaller contribution of the environment to the phenotype (Singh, 1990). For a character with low heritability $(<40 \%)$, selection may be considerably difficult or virtually impractical due to the masking effect of environment on the genotypic effects (Singh, 1990). Thus, in the present study, selection of accessions based on seed number/plant and seed yield/plant would be more satisfactory to increase seed yield of coriander.

The genetic advance and genetic advance as percent of mean was larger for number of seed number/plant, seed yield/ha and umbels/plant; moderate for days to start $50 \%$ flowering and days to end $50 \%$ flowering, days to reach $50 \%$ maturity and seed yield/plant; and lowest for umbellets number/umbel and essential oil content (Table 2). Johnson et al. (1955) indicated that the estimate of heritability and genetic advance should always be considered simultaneously as high heritability is not always associated with high genetic gain. The utility of heritability estimates increased when they are used in conjunction with genetic advance expressed on a percentage of mean (Johnson et al., 1955; Allard, 1960). In addition, Panes (1957) reported that association of high heritability with high genetic gain is due to additive gene effect. In the present study, the overall highest value of heritability and genetic advance as percent of means was found higher for longest basal leaf length, umbel/plant, seed number/plant, seed yield/plant, seed yield and fatty oil content (Table 2). Therefore, selection based on these traits could predict the performance of the progenies.

The data presented in the preceding five paragraphs had shown the presence of substantial variability in Ethiopian coriander accessions. Hence, the possibility for further improvement using these variations is wide. Therefore, some of the major economical traits of coriander such as seed yield essential and fatty oil contents which are important for consumption, processing and trade can possibly be improved for their quality and quantity through selection.

\section{ACKNOWLDGEMENT}

The financial assistance of CIDA/UPCD project is sincerely acknowledged and Dr. Sheleme Beyene, CIDA/UPCD project coordinator, is also acknowledged for his allowance to use the available facilities of the project. We thank Dr. Bizuayehu Tesfaye for his unreserved comments and suggestions, and Dr. Hussaien Mohammed for statistical analysis. We thank W/t Zewdnesh Damtew, W/t Shewanesesh Habte, Ato Solomon Abate, Ato Zerihun Jomba and Ato Taddese Debele for their assonance in field work and laboratory analysis.

\section{REFERENCES}

Adam, A., Getinet, A. and Kebede, W. 2007. Agronomic Characters and Oil Contents in Black Cumin (Nigella sativa L.) Ethiopian Journal of Agricultural Science 23:1-16.

Allard, R.W. 1960. Principles of plant breeding. John Willy and Sons., Inc., New York. 663pp.

Arganosa, G.C., Sosulski, F.W. and Slinkard, A. E. 1998. Seed yields and essential oil of northerngrown coriander (Coriandrum sativum L.). Journal of Herbs, Spices and Medicinal Plants 6(2):23-32.

Burton, G.A. and Dorane, E.H. 1953. Estimation of heritability in tall Festca (Festuca arundinacea) from replicated clonal material. Agronomy Journal 45:478-479.

Delaquis, P.J., Stanich, K., Girard, B. and Mazza, G. 2002. Antimicrobial activity of individual and mixed fractions of dill, cilantro, coriander and eucalyptus essential oils. International Journal of Food Microbiology 74:101-109.

Diederichsen, A. 1996. Coriander (Corianderum sativum L). Promoting the conservation and use of underutilized and neglected crops. 3. Institute of Plant Genetics and Crop Plant Research, Gaterslbebn/International Plant Genetic Resources Institute, Rome, Italy. 83pp.

Ensminger A.H, and Esminger, M.K.J. 1986. Food for health: A Nutrition Encyclopedia. Clovis, California: Pegus Press, USA. 
Guenther, E. 1972. The production of essential oils: Methods of distillation, enflorage, maceration and extraction with volatile solvents. In: Guenther, E. (Ed.), pp. 68. The Essential Oils. History-Origin in Plants. Production Analysis. Kreieger Publ. Co. Malabar, Florida, USA. 427pp.

Hedburg, I and Hedburg, O. 2003. Flora of Ethiopia and Eritrea Apiaceae to Dipsacaceae. Hedeger, I., S. Edwards and Sileshi Nemomsa (Eds.). Volume 4, Part 1. Uppsala, Sweden. 352pp.

Holland, B., Unwin, I.D. and Buss, D.H. 1991. Vegetables, Herbs and Spices. $4^{\text {th }}$ ed. Cambridge, UK. 163pp.

Jansen, P.C.M. 1981. Spices, condiments and medicinal plants in Ethiopia; their taxonomy and agricultural significance. Center for Agricultural Publishing and Documentation, Wageningen, Netherlands. 294pp.

Johnson, H.W., Robinson, H.F. and Comstooc, R.E. 1955. Estimates of genetic and environmental variability in soybeans. Agronomy Journal 47:314-318.

Kubo I., Fujita K., Kubo A., Nihei, K. and Ogura, T. 2004. Antibacterial activity of coriander volatile compounds against Salmonella choleraesuis. Journal of Agriculture and Food Chemistry 52(11):3329-3332.
Miller, P.A., Williams, J.C., Robinson, H.F. and Comstock, R.E. 1957. Estimates of genotypic and environmental variances in upland cotton and their implications in selection. Agronomy Journal (50):126.

Panes, V.G. 1957. Genetics of quantitative characters in relation to plant breeding. Indian Journal of Genetics 17:318-328.

Romanenko, L.G., Nevkrytaja, N.V. and Kuznecova, E.J.U. 1991. Features of pollination in coriander. Moscow, Russia.pp. 16-17. In: Diederichsen, A. 1996. Coriander (Corianderum sativum L). Promoting the conservation and use of underutilized and neglected crops. 3. Institute of Plant Genetics and Crop Plant Research, Gaterslbebn/ International Plant Genetic Resources Institute, Rome, Italy. 83pp.

SAS Institute, 2001. SAS software. SAS Institute INC., Cary. NC.USA.

Shewell-Cooper, W.E. 1973. The complete vegetable grower. Faber and Faber Ltd., 3 Queen Square, London, UK. 292pp.

Singh, B.D. 1990. Plant breeding: Principles and methods. Kalyani Publishers, New delhiLudhiana, India. 458pp. 